\title{
The Intended Consequences of the Social Assistance Grants in South Africa
}

\author{
Priscilla Gutura \\ PhD Student (Social Work), University of Fort Hare \\ Email: priscillagutura@gmail.com \\ Prof. Pius Tangwe Tanga, PhD \\ Department of Social Work / Social Development \\ University of Fort Hare, PB X1314, Alice 5700, South Africa \\ Email: tanga8_2000@yahoo.co.uk/ptangwe@ufh.ac.za
}

\section{Doi:10.5901/mjss.2014.v5n2p659}

\begin{abstract}
This paper was drawn from a broader study conducted on the role of social grants in Ngqwushwa Local Municipality in the Eastern Cape Province in South Africa. The study used a sample of 541 beneficiaries who were either administered questionnaires, interviewed or participated in focus group discussions. The aim of this paper is to explore whether the intended consequences of the social grants are being achieved among the poor rural population. The results of the study have identified social grants as effectively targeted; because of its relatively efficient targeting, social grants are by far the category of government expenditure that most concentrates its benefits on the poorest. It emerged that social grants improve both the welfare of beneficiaries and their entire households. Also, there is support of the investment in productive assets, both human and capital. The grants money is further used for education expenditure that includes school fees, transport and uniforms. The money is used even to upgrade/construct houses; buy clothes and payment of water, electricity and other bills. Thus the grant money is used by beneficiaries in a number of ways, some urbane, some less so. However the study confirms that the poor are well aware of their individual needs and some of the intended consequences of the social grants are remarkable. However, the issue of poverty still remains as a major problem.
\end{abstract}

Keywords: social grants, poverty, intended consequences, beneficiaries, rural households

\section{Introduction}

The distinctive South African historical context largely structured the social security arrangement that the new African National Congress (ANC) government enforced after gaining independence from the Apartheid regime. The South African Constitution clearly placed the right to social assistance in Section 27(1) (c) and it states that, "Everyone has a right to social security including appropriate social assistance if they are unable to support themselves and their dependents". South Africa can be said to have a well-developed social security system, largely on par with the social security systems of developed countries and unlike those in place in other developing countries (Smit and Mpedi, 2010). The state is instructed to progressively realize this right subject to its own available resources.

The South African government has therefore committed itself to halving poverty between 2004 and 2014 (Altman, Hart and Jacobs, 2009). The ANC-led government has introduced various types of poverty-alleviation measures in the past fifteen years with social assistance assuming a prominent role which includes assistance to vulnerable groups that are unable to provide for their own minimum needs. Social grants fulfil a crucial function in the poverty alleviation process and are intrinsic in helping poor households enjoy an adequate standard of living. These grants also help to ensure that the poor obtain basic human rights in terms of having a life of dignity. Social assistance grants alter the levels of inequality only marginally but have been crucial in reducing poverty among the poorest households (OECD, 2010).

Social grants have continued to be a major source of poverty reduction for millions of South Africans with over 16 million beneficiaries (South African Social Security Agency (SASSA), 2013), a number that has increased remarkably in recent years, increasing from 2.4 million in April 1998. According to SASSA (2013) it appears that increased coverage of the child support grant has driven this increase, with a projected $66.6 \%$ of all grants paid in April 2013 being Child Support Grants. Other grants with high coverage are social old-age pensions (17.9\%) and the disability grants (11.3\%). However, although the Child Support Grant has the widest reach, it is not the largest grant available. Voster (2006) also 
argues that the increase in grant uptake was facilitated by government through improvements of systems for both grant delivery and the dissemination of grant information to potential beneficiaries, coupled with changes to the eligibility criteria. Currently, South Africa has seven types of social grants in its social assistance system: Old Age Grant (OAG), Disability Grant (DG), War Veterans' Grant (WVG), Foster Care Grant (FCG), Care Dependency Grant (CDG), Child Support Grant (CSG) and Grant in Aid (GIA) (an additional grant for recipients of an old age, disability or war veteran's grant who are unable to care for themselves). All grants are awarded subject to means-tests (SASSA, 2013).

Following the announcement in the State of the Nation Address of February 10 2011, "Since we are building a developmental and not a welfare state, the social grants will be linked to economic activity and community development, to enable short-term beneficiaries to become self-supporting in the long run" (Zuma, 2011). In regard to this statement made by the president of South Africa, the evaluation of the social grants system is therefore important to determine whether the intended consequences are arising. Therefore, this forms part of the justification for this paper which aims at evaluating the social assistance grants in terms of the intended consequences, which include targeting the poor especially women and children and making beneficiaries self-supporting in the long run thereby eradicating poverty.

\section{Literature Review}

Globally, social protection is seen as a powerful tool to reduce poverty (Barrientos, 2010). Even social grants in South Africa play a critical role regarding their impact on reducing income poverty and inequality. As highlighted by Leibbrandt et al (2009), in $200854 \%$ of the population lived below the poverty line when including grant income, whereas $60 \%$ of the population would have lived below the poverty line if they had not received social assistance grants. Additionally, the expansion of the social grant system is given credit for the decline in the number of households that would report no household income (Bhorat, 2007; Everett et al, 2006). For example the period between 2001 and 2006 reported a significant drop in the incidence of households who reported no annual income. This is attributed in part to the successful identification of social grant income in these households. Notably, in many rural areas, social grants contribute as the major sources of income (Tanga and Gutura, 2013); this is less true in urban households, where a higher proportion of income comes from formal/salaried work.

However, there is a wealth of literature on social grants dwelling on the positive impact of social grants in alleviating poverty in South Africa. Hagen-Zanker, Morgan and Meth (2011) noted that social grants have a range of positive outcomes on non-monetary aspects of poverty, such as health of household members, school attendance of children and access to job opportunities. Case et al (2005) argues that these social security benefits play a critical role in the survival of households, especially those most in need, since they target them directly and reverse the bias of earlier, apartheid-era social security programmes. In addition, they have a holistic effect on household welfare and health by bringing income into the household, thereby acting as a preventive rather than a palliative intervention.

Neves et al (2009), argues that grants substantially improve the status of households, particularly in communities where social reciprocity plays such an important role: the certainty of the income makes a remarkable difference to the status of the recipient and the ability to transact with those around them. Prior research has shown that receipt of a grant of one type or another is statistically associated with lower reported hunger and higher school attendance, and that grants are often used in construction or upgrading of housing (Economic Policy Research Institute, 2005). But the research study by The Institute of Poverty, Land and Agrarian (2007), shows that grant recipients are also likely to have a higher level of activity in financial markets, both formal and informal, and are able to obtain credit on more favourable terms.

South Africa's government disability grants are considered important in providing income support to low-income AIDS patients. Indeed, anecdotal evidence suggests that some individuals may opt to compromise their health by foregoing highly active antiretroviral treatment (HAART) to remain eligible for the grant. According to Venkataramani, Maughan-Brown, and Ruger (2009), there is no evidence of people trading off their health income, there still appears to be a large financial burden associated with disability grant loss, which could increase the salience of perverse incentives, especially among those who are unable to find employment.

Also, the OAG in particular is playing a significant part in reducing poverty, given the high value of the grant compared with the mean income of the black population. Much of the earlier work on the impact of social grants on poverty focused on the success of the old age pension (Tanga, 2008) and the importance of this source of income for household security and household food security (Woolard et al, 2009; Van Der Berg, Siebrits and Lekezwa, 2010).

Even though it is now generally accepted that the social grants system provides an essential safety net for the poor and has played an important role in alleviating poverty in South Africa, poverty and inequality remains a problem. 


\section{Research Area and Methods}

The study was conducted in Ngqushwa Local Municipality (NLM) in Amathole District, which is situated within the Eastern Cape Province of South Africa. It has 118 villages with 20.757 households and an estimated population of 90.482 people. Of the total population, approximately $38 \%$ are 19 years or younger and $10 \%$ of the population are 65 years and older which means that $52 \%$ of the population are between the ages of 20 and 64 years. In terms of gender, $53 \%$ of the population is female and the remaining $47 \%$ is male. The municipal area does not display much racial diversity, with more than $99 \%$ of the inhabitants being African. The remaining $1 \%$ is comprised of coloured, white and Indian racial groups. In the municipality, $2.7 \%$ of households are headed by persons under the age of 20 years and $18.6 \%$ are headed by persons over the age of 64 years; however, $52 \%$ of households are headed by women (Statistics South Africa, 2011).

It is estimated that the number of people living in poverty in the municipality has risen from $64.19 \%$ in 1996 to $80.29 \%$ in 2005. According to Ngqushwa Local Municipality (2012), unemployment figures reach $78 \%$ thus having the highest unemployment rate (more than 20\% above the Eastern Cape average). The number of households earning less than R1500/month is estimated at $66.8 \%$ which is very high in comparison to the rest of the province. Household income levels in the area are generally low. More so, 71\% of the population earns less than R800 per month, 19\% earn between R800 and R3200 per month and only 3.9\% earns more than R3200 per month. Consequently, this influences the dependence on social grants whereby there is a high dependence on social grants with $72.5 \%$ of households receiving grants.

Mixed methods approach was employed thus, there was use of the combination of two diferrent qualitative data collection methods (in-depth interviews and focus group discussions) and one quantitative data collection method (questionnaires). The questionnaire method was selected as the first method of data collection because it was expected that it would produce varying amounts of important information and make possible the identification of notable issues for investigation during the ensuing interviews and for focus group discussions. Although the interviews and focus group discussions focused on a much narrower range of subjects, they provided the opportunity to explore in greater depth issues and concerns that could not be examined in detail in the questionnaire.

The population of the study composed of all beneficiaries of social grants in Ngwushwa municipality who amounted to a total of 65,600 (SASSA, 2012). Therefore, in selecting a sample the study employed two sampling strategies namely multi-stage sampling and purposive sampling. Multi-stage sampling was used to select the sample that was used for the questionnaires whilst purposive sampling for in-depth interviews and focus group discussions. Hence, the study consisted of 3 sets of samples; the first one consisted of 500 beneficiaries who were administered questionnaires. The questionnaire had a likert scale whereby the responses were to be given as strongly agree, agree, neutral, disagree or strongly disagree. The second set was made up of 25 beneficiaries who were interviewed using indepth interview guides. The third sample was made up of 16 beneficiaries who were selected for the 2 focus group discussions.

\section{Findings}

This section provides the findings of the study.

\subsection{Biographical information of participants}

The study had $56.0 \%$ female participants and $44.0 \%$ were male. The majority $(90.0 \%)$ were blacks whilst $10.0 \%$ were coloureds. However, there were no White or Indian participants. Among the total participants $(N=541)$, in terms of marital status, the highest number of participants (42\%) were single; $16 \%$ were widows; $12 \%$ were cohabitating; the separated category was made up of $10 \%$ and the least number of participants was found in the divorced category which was made up of $2 \%$ of the participants.

The levels of educational qualifications in the study comprised of primary, secondary, matric and tertiary education. Those who were educated up to secondary level were represented by a substantial number that is $54 \%$. Compared to those falling in other levels of educational attainment, these were found to be in the majority. Sixteen percent had some primary education; $14 \%$ had tertiary qualifications whilst the least number of participants had matriculated (12\%). The results signify that the majority of the respondents in the study were not employed thus constituted $92 \%$ whilst only $8 \%$ indicated that they were employed. 


\title{
4.2 Targeting the poor
}

Regarding the composition of their households, most respondents in the quantitative survey (43.8\%) stayed with 3-4 children followed by those that had 1-2 children (30.2\%). Those that had more than 6 children were $12.0 \%$ and $14 \%$ had children between 5 and 6 . However, no respondent cited that they stayed in a household which had no child. As shown by the qualitative results, most households had children who were ranging from 3-4 in numbers. This was highlighted by 18 participants followed by five who indicated that they had between 1-2 children in their households. Two grandmothers indicated that they had 5-6 children in their care. It is noteworthy that many of the rural grandmothers cared for orphans with a kin relation and generally felt that they had no other option. This is reinforced by a cultural and moral obligation to take up orphan care to retain children within the family circle. One particular grandmother who was 70 years old related this Zulu saying: "Abantwana babantwana bami bafana nezingane zami" (these children are my child's children so I will take care of them). She further explained that:

In this home I am staying with my 6 grandchildren. I am the one who is taking care of them. The eldest is 12 years old and the youngest turned 3 years last month. My daughters gave birth to these children and they were brought to me since the other one died of HIVIAIDS and some have remarried. I am their grandmother I have no other option. (Participant A)

Nevertheless, taking care of these children was out of love and affection for some of the participants. The other 68 year old grandmother who had four children in her care mentioned that:
I love these kids so much and I could not refuse to stay with them, remember children are just innocent souls. They keep me company as you can see I am a widow my husband died a long time ago. You see this little one is like my own the mother died when she was only 6 months. The bond we have is tremendous. (Participant $B$ )

However, viewed from a different perspective the focus group discussions highlighted the fact that some grandmothers who had many children in their care was not out of love but were after the foster care grant.

Additionally, in terms of adult composition in beneficiaries' households, the quantitative results indicated that the highest number of respondents (56.2\%) lived with 1-2, $24 \%$ with 3-4 and $11.8 \%$ with $5-6$ adults. Notably, $8.0 \%$ of the respondents designated that there were no adults staying in the household. Even in the qualitative results, three participants highlighted that there were no adults in their households. This means that these households were child headed households. One 15 year old participant highlighted that:

\begin{abstract}
When our parents died three years ago we started to stay with my aunt but she got married last year and left us alone and no one wants to stay with us. Right now I am staying with my brother and sister in our parents' house. My brother is the eldest he is 18 years, I am 15 and my younger sister is 8. (Participant D)
\end{abstract}

Further, in terms of the heads of the households, 18 participants came from female headed households and seven from male headed households. Of the 18 that indicated that women were heading the households, it was noted that six indicated that they were grandmothers, two were aunts and eight were mothers. In the male headed households four were grandfathers and two were fathers.

The research explored the attitudes of beneficiaries on how they viewed themselves and others as beneficiaries, whether they deserved the social grants. The quantitative results pointed out that the majority of the respondents believed that most people who received the grants deserved them. This was shown by $22 \%$ of the respondents who strongly agreed and 34\% who just agreed. Nevertheless 34\% remained neutral. The least number of respondents disagreed that beneficiaries deserved social grants and these only made up 10\% of the total respondents. Notably no respondent strongly disagreed.

The qualitative results showed mixed feelings among participants. While, 13 participants highlighted that beneficiaries really deserved the grants, 10 indicated that some beneficiaries did not deserve them whilst two showed that they would not judge others. One of the participants revealed that:

I believe that we surely deserve these grants. Look at how poor we are (pointing at her dilapidated house). If the government could not cater for us we would die of hunger and poverty. The government is doing a great job by assisting us. (Participant $A$ )

On the other hand, one concerned grandmother said: 
There are some cases where people do not deserve grants but they are getting them. For example one of the community members here is getting the grant but she is having a good job. Other teenagers here also misuse these grants. So those people do not deserve to be getting the grants at all. (Participant B)

Nevertheless, when the participants were asked to indicate the reasons that influenced their decisions to seek a grant, a number of reasons emerged. One of the themes that emerged was the financial instability in their households that forced them to make the choice of taking advantage of the opportunity provided for by the government. Other reasons cited by participants ranged from poverty, hunger and lack of maintenance from paternal individuals. A 36 year old man who was disabled indicated that:

As soon as I got aware of the fact that I was eligible to get a grant I went to the social worker's office to be assisted in getting the grant. With this my disability [pointing to his amputee legs] I cannot do any job that can give me money. My family was living in poverty because I could not take care of them as a man of the house. But now I can say that was a breakthrough that came to us. (Participant C)

Further, all three beneficiaries of Foster Care Grant indicated that they had to seek for the grant because they had to take care of the children that were left in their care when their parents died, primarily of HIV and AIDS. One participant said:

I desperately needed the money to be able to take care of my friend's kids. I am working as a till operator and the money that I get is not enough to cater for the whole family. One of the children is HIV positive so she needs special diet which I could not afford, so the grant supplements the little that I have. (Participant E)

In addition a 70 year old grandmother mentioned that:

I never used to get the grant and I was struggling to provide for my grandchildren. I was told that I now qualify to get the money involved for fostering my grandchildren. I applied for the grant through the assistance from a local social worker this year. (Participant $A)$

\subsection{Social grants and housing construction}

One of the questions posed to the respondents was focused on the construction and upgrading of the houses that they were staying in. From the results it is clear that the majority (48\%) denied using the money for upgrading the houses. These respondents were categorised into $42 \%$ who disagreed and $7 \%$ who strongly agreed. On the other hand, $18 \%$ of the respondents agreed. Of all the respondents $34 \%$ remained neutral with no respondents (0\%) who strongly agreed. However, in trying todistinguish the variability that might be found in the uses of the grant, the results were crosstabulated to find out the frequency and percentage of each grant type on construction. The results are tabulated in Table 1.

Table 1: Cross tabulation results of the use of each grant type on construction of houses

\begin{tabular}{|l|c|c|c|c|c|}
\hline \multicolumn{7}{|c|}{ I have used the grant's money to upgrade or construct my house } \\
\hline Type of social grant & Agree & Neutral & Disagree & Strongly disagree & Total \\
\hline \multirow{2}{*}{ Old Age Grant } & 89 & 30 & 40 & 20 & 179 \\
\cline { 2 - 7 } & $49.7 \%$ & $16.8 \%$ & $22.3 \%$ & $11.2 \%$ & $100.0 \%$ \\
\hline \multirow{2}{*}{ Disability Grant } & 0 & 40 & 69 & 0 & 109 \\
\cline { 2 - 7 } & $0.0 \%$ & $36.7 \%$ & $63.3 \%$ & $0.0 \%$ & $100.0 \%$ \\
\hline \multirow{2}{*}{ Child Support grant } & 40 & 81 & 169 & 10 & 300 \\
\cline { 2 - 7 } & $13.3 \%$ & $27.0 \%$ & $56.3 \%$ & $3.3 \%$ & $100.0 \%$ \\
\hline \multirow{2}{*}{ Foster Care Grant } & 30 & 50 & 50 & 0 & 130 \\
\cline { 2 - 7 } & $23.1 \%$ & $38.5 \%$ & $38.5 \%$ & $0.0 \%$ & $100.0 \%$ \\
\hline \multirow{2}{*}{ War Veterans Grant } & 10 & 10 & 0 & 0 & 20 \\
\cline { 2 - 7 } & $50.0 \%$ & $50.0 \%$ & $0.0 \%$ & $0.0 \%$ & $100.0 \%$ \\
\hline \multirow{2}{*}{ Care Dependency Grant } & 10 & 0 & 0 & 0 & 10 \\
\cline { 2 - 6 } & $100.0 \%$ & $0.0 \%$ & $0.0 \%$ & $0.0 \%$ & $100.0 \%$ \\
\hline
\end{tabular}


It is indicated in Table 1 that among the respondents who were receiving the Old Age Grant who had a 49.7\% interval agreed to using the money for construction whilst $11.2 \%$ strongly disagreed. The majority of the Disability Grant respondents (63.3\%) disagreed that they used the money for construction or upgrading of houses. Further, out of the 300 respondents who were receiving the Child Support Grant, 56.3\% disagreed and only 13.3\% agreed. Among the 20 respondents who were receiving the War Veteran's grant $50 \%$ agreed whilst the other $50 \%$ were neutral.

During the focus group discussions held the participants were required to mention what they used the grants money for. In the both the groups a significant number of participants (10) mentioned that they used the grants money to upgrade their houses. The remaining 6 participants mentioned that they were not using the grants money for that purpose. One participant commented that:

I have managed to extend the RDP house that I was given because my family was growing and we could not fit into the 2 rooms. My children are getting older so they needed their own room. I used the money from the grant to build that extra room. (Participant 1)

Another 70 year old participant who was interviewed said:

At one point my roof was leaking during the rainy season so I used the grant to renovate the roof. That was the only time I used the grant for upgrading my house. Otherwise I would want Buhle [name of the orphan] to have better life and to build a separate room for him because he is getting old. (Participant A)

\subsection{Payment of school fees}

The importance of education is enshrined in the Millennium Development Goal number two, "Achieve universal primary education with a target - Ensure that by 2015 , children everywhere, boys and girls alike, will be able to complete a full course of primary schooling." Data from the survey conducted, indicated that the majority of the respondents (40\%) strongly agreed that they were paying school fees with the money. In addition 32\% also just agreed. Nevertheless, $20 \%$ disagreed, $6 \%$ were neutral and the least number of respondents (2\%) strongly disagreed.

The data from the qualitative results revealed that the prospect of children's education was seen as the gateway for future independence. All the participants in the focus group discussion highlighted that they were using the grants money to pay fees. During the focus group discussion one participant mentioned that:

\section{At least we have all mentioned that we use the grant for education of our children. We want our children to go to school, that is the only hope for their future. If they are educated they can have a career because today without a career you are going nowhere. (Participant 2)}

Further, 19 of the participants who were interviewed highlighted that they were using the grants money to pay fees for children at school, two said that they were paying for infants at crèche and four, however, denied paying any fees with the grants money. A 28 year old female student said:

Since I am currently studying at the university, I do not want to burden my mother taking care of my child during the day because she is working. So during the day I leave my child at a nearby crèche. I use the grants money to pay for that service. (Participant $G$ )

The survey also sought to understand whether the grants money had the capacity to cater for children who were in any tertiary institution. Therefore, when the respondents were asked whether they were paying any tertiary fees for someone, $6 \%$ and $8 \%$ strongly agreed and agreed, respectively. Those that were neutral made up $4 \%$. A significant number, $66.2 \%$, disagreed and $15.8 \%$ strongly disagreed. Even in the focus group discussion no one mentioned that they were paying any tertiary fees with the grants money. One participant highlighted that:

I wish the government can have bursaries for our children after attaining 18 years when entitlement to grants ceases. This will help our children with their education because they will be able to finish school and careers like what have been mentioned before and make life for their own, good life to say the least. (Participant 2)

\subsection{Payment of bills}

In terms of payments of rent, electricity and water bills a large number of respondents (32\%) agreed and the least 
number of respondents (18\%) strongly agreed. Twenty percent mentioned that they never used the money to pay bills by strongly disagreeing, a further $16 \%$ disagreed and $14 \%$ were neutral. However, in the focus group discussions when the participants listed the things they used the social grants for eight participants used the money for payment of rental and other bills. Table 2 shows the uses of social grants money highlighted.

Table 2: Uses of social grants money

\begin{tabular}{|l|c|}
\hline \multicolumn{1}{|c|}{ Item } & Number of participants \\
\hline Buying food & 16 \\
\hline Paying for Education & 13 \\
\hline Paying Rentals and Other Bills & 8 \\
\hline Buying medicine & 5 \\
\hline Transportation & 3 \\
\hline
\end{tabular}

Transportation was at the bottom of the list with only three participants mentioning that they used the money for transportation. Also, in the quantitative survey, the results show that $37.8 \%$ disagreed, $24 \%$ were neutral, $22 \%$ agreed, $12.2 \%$ strongly disagreed and $4 \%$ strongly agreed. Among the 25 interviewed participants, 10 mentioned that they used the grants money to pay for transport when travelling whilst 15 participants did not mention the use of grants in transportation. One participant said,

When I go to town to buy groceries I get the money for transport from the grant that I am receiving. The shops in town are cheaper than our local spaza [small] shops. Even sometimes when I take the children to the hospital we use the grants money because at the local clinic there is no doctor. (Participant $B$ )

\subsection{Self-supporting beneficiaries}

In terms of investments, the respondents were asked to indicate whether they had invested the money they were receiving into any business/activity to empower themselves. From the data collected in the quantitative survey it became clear that most respondents did not make any investments when they started to receive social grants. From the responses given, a significant number (60\%) disagreed with $6 \%$ more strongly disagreeing. Despite the majority that did not invest into anything there were some who did. The results confirmed that $8 \%$ strongly agreed to have invested as well as $16 \%$ who agreed. Nonetheless, $10 \%$ remained neutral.

Further, the interview results indicate that out of the 25 participants, 15 mentioned that they did not invest the money into anything. On the other hand 10 participants agreed that they had made some investments. Among these 10 participants, two had invested into gardening, three had started poultry projects and five mentioned that they were saving into banks. One 52 year old female said:

As much as I have an account for my children, the grant money does not go back to the bank because I have to buy clothes, pay school fees. I mean the grant is not enough even for food. So at the end of the day I cannot invest into any business. Maybe I am investing into the future of my children but I wish the government can give us more so that our children could go to universities. (Participant F)

However, a 36 year old disabled man explained that:

Since I started to receive the grant, I have managed to start a poultry project. We managed to build the place where we keep the chickens and buy the equipments necessary. Although it's not a big place but we are managing to rear the chickens and sell them to the local people and get some income. (Participant C)

Further, as far as gender is concerned, of the total 280 female respondents, half (50\%) disagreed that they had invested. However, $17.9 \%$ agreed as well as $14.3 \%$ more who strongly agreed. Taking a look at the male beneficiaries, from the total male respondents who made up 220 respondents the majority $72.7 \%$ disagreed to investing the grants money they were receiving. Nevertheless $13.6 \%$ agreed that they were investing.

In further analysing the data, cross tabulation was performed to review the relationship that could be found between the type of grant being received and the ability to invest. The results shows that the majority of the respondents (44.1\%) who were receiving the Old Age Grant disagreed that they were investing the money and $27.9 \%$ agreed that they were investing. The results further show that among the disability grants respondents $54.1 \%$ indicate that they did 
not invest hence they answered by disagreeing. Nonetheless, 18.3\% strongly agreed that they had invested.

With the Child Support Grant, the results suggest that the majority of the respondents (63.3\%) disagreed to investing the money into any activity whilst only $20.0 \%$ agreed with the remaining $16.7 \%$ being neutral. Out of all the respondents who were receiving the Foster Care Grant, $61.5 \%$ argued that they disagreed to investing the money. Among those that were receiving the War Veterans grants, out of the 20 respondents 10 suggested being neutral whilst the other 10 disagreed. These had a 50\% rate each. The Care Dependency grant had 100\% respondents who articulated that they agreed to have invested the money.

Furthermore, the quantitative survey required the respondents to select the type of investments they had ventured into. Figure 1 shows the type of investments that were made by the respondents.

Fig 1: Types of investments made by respondents

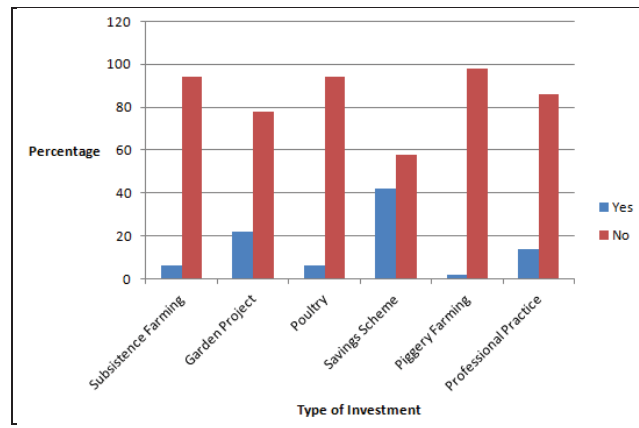

Figure 1 shows that among those that had mentioned that they were investing, the majority of the respondents who consituted $42 \%$ were keeping their money in savings schemes. Professional practice was only invested into by $14 \%$ of the respondents and $86 \%$ did not. The least type of investment that had the least number of respondents was piggery farming which had only $2 \%$ of the respondents.

\section{Discussion}

Indeed, social grants have played a very critical role in targeting a large number of poor people especially women and children. The results of the study have highlighted that many households that were receiving social grants were composed of children. It is therefore noted that the vast majority of grants go to the poor children who need them even in child headed households. This supports an analysis of the General Household Survey (GHS) of 2005 by Leatt and Budlender (2006) which showed the effectiveness of targeting grants to households with children, and it highlighted that income from grants increased dramatically as monthly earnings decreased.

As HIV and AIDS continue to affect the life-spans of parents, more and more children are being orphaned. It is understandable that child headed households therefore will also continue to rise. The problematic issue is that there are very limited safety nets for orphaned children. However, as the results of the study have conceded, there are some children in child headed households who are accessing social grants. The Department of Social Development in its budget has included the delivery of social grants, such as the Child Support Grant to the child headed households. Nevertheless, vulnerable children especially the orphans need additional support that can be argued as not necessarily monetary in nature. This is because these children would have lost their primary caregivers. One might argue that, what aggravates the lack of support of these children is that in South Africa there is a shortage of social workers who can be responsible for the identification of vulnerable children and therefore support them with the necessary means.

Statistics from the Department of Health, Medical Research Council and OrCmacro (2007) assert that, in South Africa, women head nearly half of all households. The primary reasons for female-headship have traditionally included male labour migration and non-marriage as stipulated by Posel (2001). However, Goebel, Dodson and Hill (2010) accentuated that although female headship in this context is connected to historically patterns of patriarchy and apartheid that are unique to South Africa; female headship increasingly is connected to contemporary macro-economic conditions. Gilbert, Seliko and Walker (2010) further suggest that premature death brought on by HIV and AIDS is a contributor too.

Various studies (Van der Berg, Louw and Dutoit, 2009 and Van der Berg, Siebrits and Lekezwa, 2010) have 
confirmed that social grants are well targeted. Since the inception of social grants, there has been a rapid increase in the number of beneficiaries. In 1998 there were 2.5 million beneficiaries. These numbers have increased to 16.1 million in 2012/2013 which means that the number has increased by 544\% in the past 14 years, (Statistics South Africa, 2012). According to Vorster (2006), the increase in grant uptake was facilitated by government through improvements of systems for both grant delivery and the dissemination of grant information to potential beneficiaries, coupled with changes to the eligibility criteria. Recently, a high court in South Africa in 2013 ruled out that grandparents who cared for their grandchildren are eligible for foster care grants regardless of their income.

However, the need for housing is a social issue that impacts negatively on the lives of the poor. But the inability of the poor to access good housing stems from not only the inability of government to provide for these services but primarily from their lack of income to provide for these social necessities. Nevertheless, the results of the study point to the notion that beneficiaries may use the grants to construct/ upgrade their houses if need be.

Many poor children cannot attend school due to the costs associated with education. Additionally communities that are resource-constrained have lower quality educational services which negatively affect enrolment rates. Poverty therefore erodes opportunities for children and youth to attend school. This causes a vicious cycle of destitution by undermining the household's capacity to accumulate the human capital necessary to break the poverty trap. Social security is important to harness the educational potential as it delivers benefits not only to the individual but to the whole of society in terms of poverty reduction and economic development.

The results of the study however points to the fact that by receiving social grants, recipients are countering these negative effects by being provided for with money to finance education. Samson et al (2004) mentioned two ways in which social grants help in education. Firstly, the grant can be used for costs such as books and transport. Secondly, the grants offset the opportunity cost of attending school. Additionally, parents pay school fees which might improve the quality of education. A more logical approach was adopted by Leatt and Bundlender (2006) when they concluded that households in the lowest income category and most eligible for social transfers are more likely to spend on education. Hence it can be surmised that the current social grants arrangement is improving utilisation and access of education services.

As indicated in the findings of the study, the social grants has improved the lives of the children by providing them with the opportunity to attend crèche or school, that is through being able to pay school fees and buy school uniforms. The ability of child social grants and even other grants not meant for children in affording children the right to education is a marker of their positive social impact on beneficiaries. The positive impact of social grants on schooling is also supported by anecdotal evidence. Lund (2002: 687) describes the monthly markets that form in poor, underserved rural areas on pension payment days as vibrant sites of economic activity where pensioners pay their funeral policies, school principals come to collect school fees, and fresh food and clothing is bought and sold.

Economic theory suggests that social grants, by raising incomes, affect education in three ways. First, the increase in a disposable income, provided by the social grant, could help pay the otherwise unaffordable costs of attending school since there are financial barriers to school attendance like purchasing school supplies, uniforms, tuition and transportation. Second, a grant could relieve the opportunity cost of school attendance because, with a cash transfer in hand, a family is more likely able to do without a child's contribution to household income in favour of making a long-term investment in education. Third, by indirectly increasing the resources available to schools, the quality of education may improve, making education a more attractive option to households.

Moreover, the results of the study outline that receiving a social grant enables a beneficiary to invest as some participants indicated that they had invested. This is in line with the findings made by Vincent and Cull (2009) when they jointly concluded that social transfers prevent distress sales and allow for capital investment in productive activities, enabling the beneficiaries the chance to protect and improve their economic situation. Therefore it is safe to say that social security increases or permits continuation in investment thereby assisting in raising the productivity of the poor and enables them to participate in the economy. Govender (2011) argues that nonetheless social security is not only dispensed for humanitarian reasons or for political expediency but has economic merits as well. In this regard, besides providing households with the means to satisfy their consumption needs social security provides a means for saving and investments. However, not all beneficiaries are investing, most notably because of the insufficiency of the grants.

Although savings behaviours are noted in relation to the larger value grants, savings behaviours are also evident in relation to the lower Child Support Grant. More importantly, nevertheless, is that the research findings point to the significance of social grants in investments in productive assets and physical capital. Receipt of a social grant is associated with a range of financial market engagements and behaviours, such as elevated levels of savings and investment. Even though this issue is relatively under-researched in the South African context, the findings are consistent 
with the investment effect noted in international literature (Barrientos and Hulme, 2008; Grosh et al, 2008). Therefore the findings of this study show that some beneficiaries made some investments in improving their lives although they were few. Therefore, the results of the study point out to the findings by Neves et al (2009) who found out that social grants in South Africa generate economic benefits such as mitigating risks, facilitating savings and investments and supporting the development of local markets.

\section{Conclusion}

In the context of large-scale poverty and unemployment, as well as the present economic downturn, it is probable that reliance on grants will continue, if not increase. However what is extensively debated upon is whether social grants are really reducing poverty or they are just reducing suffering. Obviously, social grants on their own will not be able to resolve the issues of poverty and inequality but they make an important contribution and they continue to do so for the foreseeable future.

\section{References}

Altman, M.; Hart, T. and Jacobs, P. (2009). Household food security status in South Africa. Agrekon, 48 (4): 36- 49.

Barrientos, A. (2010) Social Protection and Poverty. Social Policy and Development Programme Paper 42. Geneva: UNRISD.

Barrientos, A. and Hulme, A. (2008). Social protection for the poor and the poorest: An introduction. In, Barrientos, A. and Hulme, A. (eds). Social protection for the poor and the poorest: Concepts, policies and politics. London: Palgrave MacMillan: 123-127.

Bhorat, H. (2007). Welfare Shifts in the Post-Apartheid South Africa: A Comprehensive Measurement of Changes.' Working Paper 07/128. Cape Town: DPRU, University of Cape Town.

Case, A.; Hosegood, V. and Lund, F. (2005). The Reach and Impact of Child Support Grants: Evidence from KwaZulu-Natal. Development South Africa, 22(4): 467- 482.

Department of Health, Medical Research Council and OrCMacro Department of Health (2007). Demographic and Health Survey. South Africa: Pretoria.

Everett, D., Smith, M. and Solanki, G. (1997) Baseline Survey of the 21 ISRDP and URP Nodes: Topline Report and Data Tables. Pretoria: Department of Social Development.

Gilbert, L.; Seliko, T., Walker, L. (2010). Society, health and disease in a time of HIVIAIDS. Johannesburg: McMillan.

Goebel, A., Dodson, B. and Hill, T. (2010). Urban advantage on Urban penalty? A case study of female headed households in a South African city. Health and Place, 16(3): 573-580.

Govender, M. (2011). Conditional Cash Transfer as a means of addressing poverty in South Africa. PhD Thesis. University of South Africa.

Grosh, M.; Del Ninno, C.; Tesliuc, E. and Ouerghi, A. (2008). For protection and promotion: The design and implementation of effective safety nets. Washington: World Bank. [Online] Available: at http://www.foodsecurity.gov.kh/otherdocs/World-Bank-ForProtection-and-Promotion-Eng.pdf. (July 21, 2013).

Hagen-Zanker, J., Morgan, J and Meth, C. (2011). South Africa's cash social security grants: Progress in increasing coverage. London: ODI Publications.

Leatt, A. and Budlender, D. (2006). Under what conditions? Social security for children in South Africa. [online] Available: www.unicef.org/socialpolicy/files/Under_what_conditions_Social_Security_for children_in_South_Africa.pdf (March 12, 2013).

Leibbrandt, M., Woolard, I., Finn, A. and Argent, J. (2009). Trends in South African Income Distribution and Poverty Since the Fall of Apartheid. Social, Employment and Migration Working Paper 101. Paris: OECD.

Lund, F. 2002. Crowding In Care, Security, and Micro-Enterprise Formation: Revisiting the Role of the State in Poverty Reduction and Development. Journal of International Development, 14: 68 - 694.

Neves, D.; Sampson, M.; Van Niekerk, I.; Hlatshwayo, S. and Du Toit, A. (2009). The use and effectiveness of social grants in South Africa. Research Report to the FinMark Trust. Cape Town: Institute for Poverty, Land and Agrarian Studies (PLAAS) and Economic Policy Research Institute (EPRI). [Online] Available: www.finmarktrust.org.zal.../getfile.aspx?...\%20The\%20use \%20and\%20effectiveness\%20of\%20social\%20grants\%20in... (May 13, 2012).

OECD (2010). Trends in South African income distribution and poverty since the fall of apartheid: Experts seminar. Cape Town: University of Cape Town, 4 March. [Online] Available: www.esrc.ac.uk/my.../d3c88693-ad5f-47a0-be20-195bb38d4c07 (March 14, 2011).

Posel, D. R. (2001). Who are the heads of the households, what do they do and is the concept of headship useful? An analysis of headship in South Africa. Development Southern Africa, 18(5): 651-670.

Samson, M.; Lee, U.; Ndebele, A.; Mac Quene, K.; Van Niekerk, I.; Gandhi, V.; Harigaya, T. and Abrahams, C. (2004). The social and economic impact of South Africa's social security system. Report commissioned by the Finance and Economic Directorate of the Department of Social Development. Economic Policy Research Institute (EPRI). Cape Town: Department of Social Development.

Tanga, P.T. (2008). The impact of Old Age Pension on Households and Social Relationships. Review of Southern African Studies, 12 (1 \& 2): $184-215$. 
Tanga P. T. and Gutura, P. (2013). The impact of Child Support Grant on the labour market participation by female beneficiaries. Social Work/Maatskaplike Werk, 49 (1): 128-140.

Smit, N. and Mpedi, L.G. (2010). Social protection for developing countries: Can social insurance be more relevant for those working in the informal economy. Law, Democracy and Development, 14: 159-187.

South African Social Security Agency (SASSA) (2012). Annual statistical report on social grants: 2010/11 report: South Africa: Pretoria. [online] Available: www.sassa.gov.za (April 6, 2012).

South African Social Security Agency (SASSA) (2013). Annual statistical report on social grants. [online] Available: www.sassa.gov.za (March 13, 2013).

Statistics South Africa (2011). South African Statistics 2011. [online] Available at http://www.statssa.gov.za/publications/SAStatistics ISAStatistics2011.pdf (May 10, 2013).

Statistics South Africa (2012). Poverty profile of South Africa. Application of the poverty lines on the Living Conditions Survey 2008/2009. [online] Available at www.statssa.gov.za (July 10, 2013).

Van der Berg, S.; Louw, M. and Dutoit, L. (2009). Poverty Trends since the transition: What we know. Stellenbosch Economic Working Paper 19/09.Stellenbosch: University of Stellenbosch. Bureau of Economic Research.

Van der Berg, S.; Siebrits, K. and Lekezwa, B. (2010). Efficiency and equity effects of social grants in South Africa. Working Papers. 15/2010. Stellenbosch: Stellenbosch University, Department of Economics.

Vincent, K. and Cull, T. (2009). Impacts of social cash transfers: Case study evidence from across Southern Africa. II Conferenciado IESE "Dinamicas da PobrezaePadrões de Acumulaçãoem Moçambique", Maputo, 22 e 23 de Abril de 2009. [Online] Available:http://www.iese.ac.mz/lib/publication/ll_conf/Grupoll/Social_transfers_VINCE. (August 19, 2013).

Vorster, J.H. (2006). Quantitative study on incentive structures on social assistance grants in South Africa. In, Department of Social Development (ed.) Report on the incentive structures of social assistance grants in South Africa. Pretoria: Department of Social Development.

Venkataramani, M., Maughan-Brown, A and Ruger. C. (2009). Welfare and the Incentive to Trade-Off Health for Income among Individuals on HAART in South Africa. AIDS and Behavior. Center for Social Science Research: [online] Available: http://www.cssr.uct.ac.za/sites/cssr.uct.ac.za/files/pubs/WP240.pdf-microsoft (March 31, 2012).

Woolard, I., Leibbrandt, M. and McEwen, H. (2009). "Poverty and inequality", In Hofmyr, J. (ed.). Recession and Recovery. African Minds/IJR. Capetown.

Zuma, J. 2011. "State of the Nation Address". Pretoria. February 10. 
